\title{
When Shadow Banking Can Be Productive: Financing Small and Medium Enterprises in China
}

\author{
KELLEE S. TSAI*,**
}

*Division of Social Science, Hong Kong University of Science \& Technology, Kowloon, Hong Kong SAR; **Johns Hopkins University, Baltimore, MD, USA

\section{Online Appendix}

A. Official definition of businesses by size and industry in China

\begin{tabular}{|c|c|c|c|c|c|}
\hline Industries & Category & Big & Mid & Small & Micro \\
\hline \multirow{3}{*}{$\begin{array}{l}\text { Agriculture, forestry, fisheries; } \\
\text { Industry }\end{array}$} & Revenue & $\geq 200$ mil & 5 mil to $200 \mathrm{mil}$ & $500 \mathrm{~K}-5 \mathrm{mil}$ & $<500 \mathrm{~K}$ \\
\hline & Employees & $\geq 1,000$ & $300-1,000$ & $20-300$ & $<20$ \\
\hline & Revenue & $\geq 400 \mathrm{mil}$ & $20 \mathrm{mil}-400 \mathrm{mil}$ & $3 \mathrm{mil}-20 \mathrm{mil}$ & $<3$ mil \\
\hline \multirow[t]{2}{*}{ Construction } & Revenue & $\geq 800 \mathrm{mil}$ & $60 \mathrm{mil}-800 \mathrm{mil}$ & $3 \mathrm{mil}-60 \mathrm{mil}$ & $<3$ mil \\
\hline & Total Assets & $\geq 800 \mathrm{mil}$ & $50 \mathrm{mil}-800 \mathrm{mil}$ & $3 \mathrm{mil}-50 \mathrm{mil}$ & $<3$ mil \\
\hline \multirow[t]{2}{*}{ Wholesale } & Employees & $\geq 200$ & $20-200$ & $5-20$ & $<5$ \\
\hline & Revenue & $\geq 400 \mathrm{mil}$ & $50 \mathrm{mil}-400 \mathrm{mil}$ & $10 \mathrm{mil}-50 \mathrm{mil}$ & $<10 \mathrm{mil}$ \\
\hline \multirow[t]{2}{*}{ Retail } & Employees & $\geq 300$ & $50-300$ & $10-50$ & $<10$ \\
\hline & Revenue & $\geq 200 \mathrm{mil}$ & $5 \mathrm{mil}-200 \mathrm{mil}$ & $1 \mathrm{mil}-5 \mathrm{mil}$ & $<1$ mil \\
\hline \multirow[t]{2}{*}{ Transportation } & Employees & $\geq 1,000$ & $300-1,000$ & $20-300$ & $<20$ \\
\hline & Reve & $\geq 300 \mathrm{mil}$ & $30 \mathrm{mil}-300 \mathrm{mil}$ & $2 \mathrm{mil}-30 \mathrm{mil}$ & $<2$ mil \\
\hline \multirow{2}{*}{ Storage } & Employees & $\geq 200$ & $100-200$ & $20-100$ & $<20$ \\
\hline & Revenue & $\geq 300 \mathrm{mil}$ & $10 \mathrm{mil}-300 \mathrm{mil}$ & $1 \mathrm{mil}-10 \mathrm{mil}$ & $<1$ mil \\
\hline \multirow[t]{2}{*}{ Post } & Employees & $\geq 1,000$ & $300-1,000$ & $20-300$ & $<20$ \\
\hline & Reve & $\geq 300 \mathrm{mil}$ & $20 \mathrm{mil}-300 \mathrm{mil}$ & $1 \mathrm{mil}-20 \mathrm{mil}$ & $<1$ mil \\
\hline \multirow[t]{2}{*}{ Hotel \& Accommodation } & Emplo & $\geq 300$ & $100-300$ & $10-100$ & $<10$ \\
\hline & Revenue & $\geq 100 \mathrm{mil}$ & $20 \mathrm{mil}-100 \mathrm{mil}$ & $1 \mathrm{mil}-20 \mathrm{mil}$ & $<1$ mil \\
\hline \multirow[t]{2}{*}{ Restaurant } & Employees & $\geq 300$ & $100-300$ & $10-100$ & $<10$ \\
\hline & Revenue & $\geq 100 \mathrm{mil}$ & $20 \mathrm{mil}-100 \mathrm{mil}$ & $1 \mathrm{mil}-20 \mathrm{mil}$ & $<1$ mil \\
\hline \multirow[t]{2}{*}{ Telecommunications } & Employees & $\geq 2,000$ & $100-2,000$ & $10-100$ & $<10$ \\
\hline & Revenue & $\geq 1$ bil & $10 \mathrm{mil}-1 \mathrm{bil}$ & $500 \mathrm{~K}-10 \mathrm{mil}$ & $<500 \mathrm{~K}$ \\
\hline \multirow[t]{2}{*}{ Software and IT } & Employees & $\geq 300$ & $100-300$ & $10-100$ & $<10$ \\
\hline & Reven & $\geq 100 \mathrm{mil}$ & $10 \mathrm{mil}-100 \mathrm{mil}$ & $500 \mathrm{~K}-10 \mathrm{mil}$ & $<500 \mathrm{~K}$ \\
\hline \multirow[t]{2}{*}{ Real Estate Development } & Revenue & $\geq 2$ bil & $10 \mathrm{mil}-2 \mathrm{bil}$ & $1 \mathrm{mil}-10 \mathrm{mil}$ & $<1$ mil \\
\hline & Total Assets & $\geq 100 \mathrm{mil}$ & $50 \mathrm{mil}-100 \mathrm{mil}$ & $20 \mathrm{mil}-50 \mathrm{mil}$ & $<20 \mathrm{mil}$ \\
\hline \multirow[t]{2}{*}{ Property Management } & Employees & $\geq 1,000$ & $300-1,000$ & $100-300$ & $<100$ \\
\hline & Revenue & $\geq 50 \mathrm{mil}$ & $10 \mathrm{mil}-50 \mathrm{mil}$ & $5 \mathrm{mil}-10 \mathrm{mil}$ & $<5$ mil \\
\hline \multirow[t]{2}{*}{ Lease and business services } & Employees & $\geq 300$ & $100-300$ & $10-100$ & $<10$ \\
\hline & Total $\mathrm{H}$ & $\geq 1.2$ bil & $80 \mathrm{mil}-1.2$ bil & $1 \mathrm{mil}-80 \mathrm{mil}$ & $<1$ mil \\
\hline Others & Employees & $\geq 300$ & $100-300$ & $10-100$ & $<10$ \\
\hline
\end{tabular}

Source: http://www.gov.cn/zwgk/2011-07/04/content_1898747.htm (关于印发中小企业划型标准规定的通知工 信部联企业〔2011〕 300 号) 


\section{B. Overview of NBFI regulations in China}

\section{B.1. Small loan company regulations.}

\begin{tabular}{|c|c|c|c|}
\hline Date & Regulation name & $\begin{array}{l}\text { Issuing } \\
\text { entity }\end{array}$ & Main purpose \\
\hline 2008 & $\begin{array}{l}<\text { Interim Measures for Small Loan } \\
\text { Companies }>\end{array}$ & $\mathrm{CBRC}^{\mathrm{a}}$ & $\begin{array}{l}\text { Defines the nature of SLCs, specifies conditions for } \\
\text { establishing SLCs, SLC financial sources and } \\
\text { uses, as well as their management and } \\
\text { supervision. }\end{array}$ \\
\hline 2008 & $\begin{array}{l}<\text { Notice of Policies Related to Rural } \\
\text { Banking, Small Loan and Mutually } \\
\text { Financial Cooperation }>\end{array}$ & CBRC & $\begin{array}{l}\text { Regulates statistical reporting, supervision, and risk } \\
\text { management of rural banks, loan and small loan } \\
\text { companies, and mutual financing cooperative } \\
\text { organisations. }\end{array}$ \\
\hline 2014 & $\begin{array}{l}<\text { SLC Management Measures (exposure } \\
\text { draft) }>\end{array}$ & $\begin{array}{l}\text { CBRC, } \\
\text { PBOC }^{\mathrm{b}}\end{array}$ & $\begin{array}{l}\text { Extends SLC business scope, specifies that SLCs } \\
\text { financing into banking financial institution is a } \\
\text { type of general credit business, and requires SLC } \\
\text { to implement a supervision model similar to } \\
\text { banks. }\end{array}$ \\
\hline
\end{tabular}

\section{B.2. Loan guaranty regulations.}

\begin{tabular}{|c|c|c|c|}
\hline Date & Regulation name & $\begin{array}{l}\text { Issuing } \\
\text { entity }\end{array}$ & Main purpose \\
\hline 2001 & $\begin{array}{l}<\text { Interim Measures for the Risk } \\
\text { Management of Financing Guaranty } \\
\text { Agencies for SMEs }>\end{array}$ & $\mathrm{MOF}^{\mathrm{c}}$ & $\begin{array}{l}\text { Clarifies the definition of 'financing guaranty } \\
\text { agencies for small and medium-sized enterprises'; } \\
\text { stipulates their operation mode, business scope } \\
\text { and fund application; and promotes scaling up of } \\
\text { the SMEs credit guaranty and re-guaranty system. }\end{array}$ \\
\hline 2010 & $\begin{array}{l}<\text { Interim Regulation for the } \\
\text { Administration of Financial Guaranty } \\
\text { Institutions }>\end{array}$ & CBRC & $\begin{array}{l}\text { Regulates the entry and exit, business scope, } \\
\text { operations, leverage, capital usage, investment and } \\
\text { risk management of guaranty companies. }\end{array}$ \\
\hline 2011 & $\begin{array}{l}<\text { Notice Stipulating the Cooperation } \\
\text { between Banking and Guaranty } \\
\text { Institutions }>\end{array}$ & CBRC & $\begin{array}{l}\text { Calls for long-term close cooperation between } \\
\text { banking and guaranty institutions, especially in the } \\
\text { areas of SMEs and peasant households financial } \\
\text { services. Requires banking institutions to optimise } \\
\text { SME loan approval procedures and implement the } \\
\text { corresponding preferential policies on interest } \\
\text { rates. }\end{array}$ \\
\hline 2011 & $\begin{array}{l}<\text { Notice Promoting the Regulated } \\
\text { Development of the Credit Guaranty } \\
\text { Industry }>\end{array}$ & CBRC & $\begin{array}{l}\text { Calls on local governments at all levels to perfect } \\
\text { supporting policies, optimise the external } \\
\text { environment and strengthen scientific supervision } \\
\text { of the credit guaranty industry to achieve its } \\
\text { sustainable development. }\end{array}$ \\
\hline 2014 & $\begin{array}{l}<\text { Revised Regulations for the } \\
\text { Administration of Financial Guaranty } \\
\text { Institutions (Draft) }>\end{array}$ & CBRC & $\begin{array}{l}\text { Adds clarifications to existing rules and calls for } \\
\text { higher requirements for the establishment, } \\
\text { operation, and expansion of financial guaranty } \\
\text { companies. }\end{array}$ \\
\hline
\end{tabular}




\begin{tabular}{|c|c|c|c|}
\hline Date & Regulation name & Issuing entity & Main purpose \\
\hline $2005 / 2 / 3$ & $\begin{array}{l}<\text { Foreign Investment in the Leasing } \\
\text { Industry Administration Procedures }>\end{array}$ & $\mathrm{MOC}^{\mathrm{d}}$ & $\begin{array}{l}\text { Specifies the administrative department } \\
\text { and administrative regulations of } \\
\text { foreign-invested leasing companies. }\end{array}$ \\
\hline $2010 / 9 / 8$ & $\begin{array}{r}<\text { Notice about Tax Issues of Assets Sale } \\
\text { of Lessees in Sales and Lease Back }>\end{array}$ & $\mathrm{SAT}^{\mathrm{e}}$ & $\begin{array}{l}\text { Specifies the tax issues of asset sales of } \\
\text { lessees and lease back. }\end{array}$ \\
\hline $2011 / 12 / 15$ & $\begin{array}{l}<\text { Guiding Policy about the Promotion } \\
\text { of Financial Leasing in } 12^{\text {th }} \text { Five } \\
\text { Year Plan }>\end{array}$ & MOC & $\begin{array}{l}\text { Promotes the financial leasing industry in } \\
\text { the } 12^{\text {th }} \text { Five Year Plan. }\end{array}$ \\
\hline 2013/9/18 & $\begin{array}{l}<\text { Measures for the Supervision and } \\
\text { Management of Financial Leasing } \\
\text { Companies }>\end{array}$ & $\mathrm{MOC}$ & $\begin{array}{l}\text { Specifies the supervision department and } \\
\text { management of financial leasing } \\
\text { companies. }\end{array}$ \\
\hline $2013 / 12 / 10$ & $\begin{array}{c}<\text { Interim Measures of Commercial } \\
\text { Banks Factoring Management }>\end{array}$ & $\mathrm{CBRC}$ & $\begin{array}{l}\text { Specifies the regulated measures of } \\
\text { banks' factoring businesses. }\end{array}$ \\
\hline 20131212 & $\begin{array}{l}\text { No.106 document }<\text { Notice of } \\
\text { Incorporating Railway Transport and } \\
\text { Postal Industry into the VAT Pilot }>\end{array}$ & SAT & $\begin{array}{l}\text { Announces the incorporation of the } \\
\text { railway transport and postal industries } \\
\text { into the VAT pilot. }\end{array}$ \\
\hline $2013 / 12 / 15$ & $\begin{array}{l}<\text { Notice on Strengthening Shadow } \\
\text { Banking Supervision }>\end{array}$ & State Council & $\begin{array}{l}\text { Emphasises the importance of non- } \\
\text { banking credit intermediation's } \\
\text { regulation, risk control, and division of } \\
\text { responsibility. }\end{array}$ \\
\hline $2013 / 12 / 16$ & $\begin{array}{l}<\text { Financial Leasing Company } \\
\text { Administration Measures }>\end{array}$ & CBRC & $\begin{array}{l}\text { Specifies the regulatory management of } \\
\text { financial leasing companies. }\end{array}$ \\
\hline $2013 / 12 / 20$ & $\begin{array}{l}<\text { Policy on Accelerating the } \\
\text { Development of the Aircraft Leasing } \\
\text { Business }>\end{array}$ & State Council & $\begin{array}{l}\text { Establishes policies that support the } \\
\text { aircraft leasing businesses to promote } \\
\text { the country's aircraft industry. }\end{array}$ \\
\hline $2014 / 3 / 1$ & $\begin{array}{l}<\text { Interpretation of Laws Applicable } \\
\text { Disputed Cases of Financial Leasing } \\
\text { Contracts }>\end{array}$ & $\operatorname{SPC}^{\mathrm{f}}$ & $\begin{array}{l}\text { Explains disputed legal problems in } \\
\text { financial leasing businesses. }\end{array}$ \\
\hline
\end{tabular}

Notes: ${ }^{a}$ CBRC: China Banking Regulatory Commission. ${ }^{b} \mathrm{PBOC}$ : People's Bank of China. ${ }^{\mathrm{c}} \mathrm{MOF}$ : Ministry of Finance. ${ }^{\mathrm{d}}$ MOC: Ministry of Commerce. ${ }^{\mathrm{e}} \mathrm{SAT}$ : State Administration of Taxation. ${ }^{\mathrm{f}} \mathrm{SPC}$ : Supreme People's Court. 


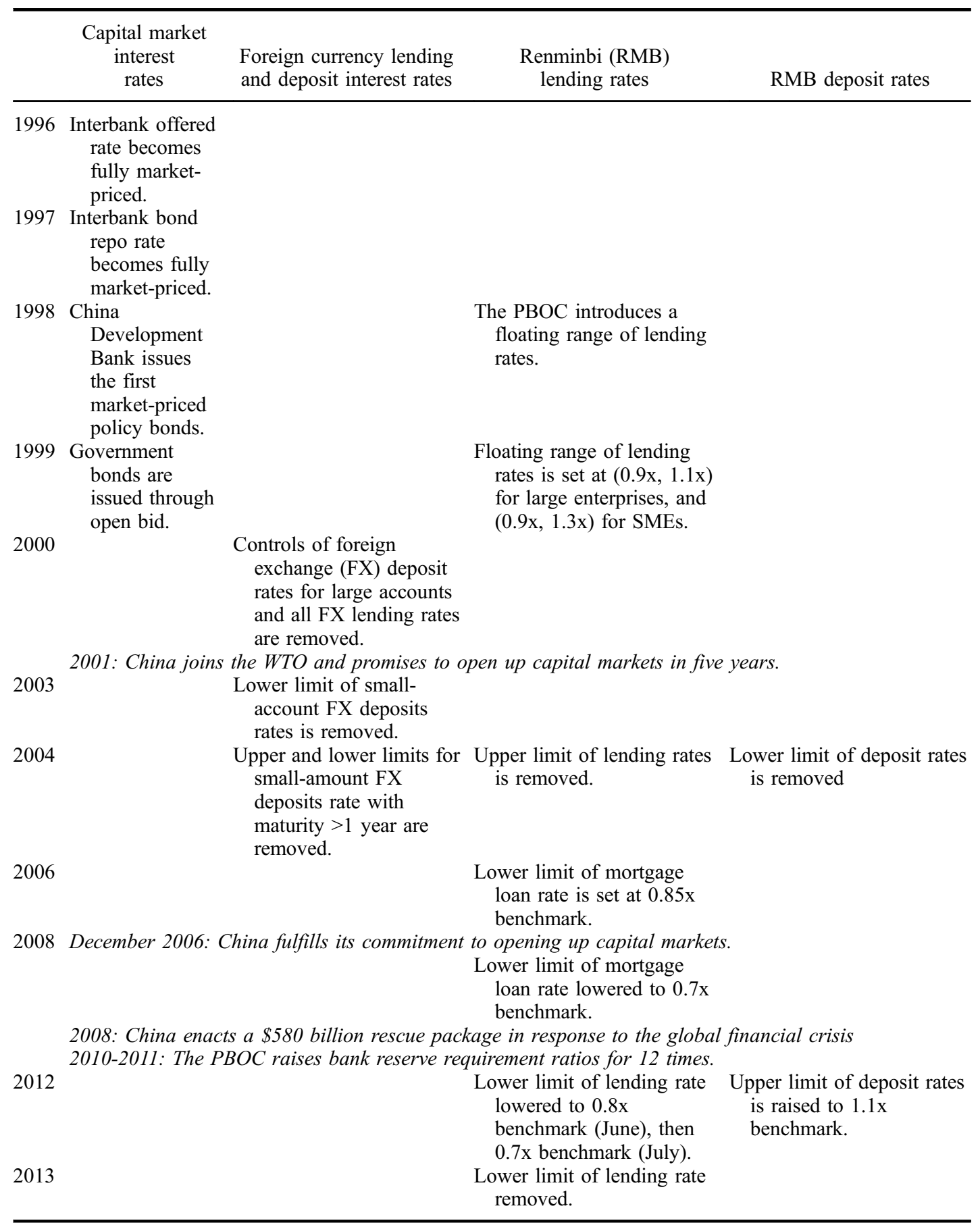



Capital market interest
Foreign currency lending rates and deposit interest rates
RMB deposit rates

Allow nine commercial banks to submit the lending rate they charge their best quality clients each day to set the prime rate.

Allow the issuance of large negotiable certificates of deposit on the interbank market.

Upper limit of deposit rates raised to $1.2 \mathrm{x}$ benchmark. raised to $1.3 \mathrm{x}$ (March), then raised to $1.5 \mathrm{x}$ (May). August: Upper limit of deposit rates removed for fixed deposits $>1$ year.

September: Upper limit of deposit rates removed for commercial banks \& rural cooperative financial institutions.

Sources: Federal Reserve Bank of San Francisco, 'China's Interest Rate Liberalization Reform' (May 2014); and People's Bank of China, at http://www.pbc.gov.cn/zhengcehuobisi/.

\section{References}

Federal Reserve Bank of San Francisco. (2014, May). China's interest rate liberalization reform. Asia Focus. Retrieved from http://www.frbsf.org/banking-supervision/publications/asia-focus/2014/may/china-interest-rate-liberalization-reform/AsiaFocus-China-Interest-Rate-Liberalization.pdf 